\title{
HUBUNGAN ANTARA IBU DENGAN KURANG ENERGI KRONIK (KEK) PADA MASA KEHAMILAN TERHADAP PERTUMBUHAN DAN PERKEMBANGAN BALITA USIA 6-18 BULAN DI PUSKESMAS CIPEUNDEUY
}

\author{
Marjani K, Shintia Anggi A \\ Politeknik Kesehatan TNI AU Ciumbuleuit Bandung \\ (MJKhoirunnisa@gmail.com)
}

\begin{abstract}
ABSTRAK
Pertumbuhan dan perkembangan anak dipengaruhi oleh faktor genetik, faktor lingkungan (faktor pranatal dan postnatal). Faktor prenatal yang paling berperan adalah status kurang energi kronis (KEK) 33,5\%. Tujuan penelitian ini adalah terdapat hubungan antara ibu dengan kurang energi kronik (kek) pada masa kehamilan terhadap pertumbuhan dan perkembanggan balita usia 6-18 bulan. Metode penelitian ini menggunakan survey analitik dengan pendekatan cross sectional, yang dilakukan pada 662 responden yang ditentukan dengan teknik total sampling. Hasil penelitian menunjukan bahwa terdapat ibu hamil dengan kek sebanyak $49(7,4 \%)$ dan ibu hamil tidak KEK sebanyak 613 (92,6\%). Pada pertumbuhan dalam kategori tidak sesuai 18 $(36,7 \%)$, dalam kategori sesuai $31(63,3)$. Untuk perkembangan anak kategori sesuai 29 $(59,2 \%)$, dalam kategori meragukan $14(28,6 \%)$ dalam kategori penyimpangan $6(12,2 \%)$. Diharapkan hasil penelitian dapat meminimalisir angka kejadian kek dan juga dapat memaksimalkan asuhan pada ibu hamil.
\end{abstract}

Kata Kunci : KEK, Pertumbuhan, Perkembangan, Balita

\section{ABSTRACT}

Child growth and development is influenced by genetic factors, environmental factors (prenatal and postnatal factors). The most important prenatal factor is Chronic Energy Deficiency (CED) 33.5\%. The purpose of this study is that there is a relationship between mothers with Chronic Energy Deficiency (CED) during pregnancy on the growth and development of infants aged 6-18 months. The method of this study uses an analytical survey with a cross sectional approach, which was carried out on 662 respondents determined by the total sampling technique. The results showed that there were 49 (7.4\%) pregnant women and 613 non-CED pregnant women (92.6\%). In growth in the inappropriate category 18 (36.7\%), in the appropriate category 31 (63.3). For the development of children the category matches 29 (59.2\%), in the doubtful category 14 (28.6\%) in the category of deviation 6 (12.2\%). It is expected that research results can minimize the incidence of kek and can also maximize care for pregnant women.

Keywords: CED, Growth, Development, Toddler

\section{PENDAHULUAN}

Tercapainya kualitas hidup yang baik bagi keluarga dan masyarakat sangat ditentukan oleh kesehatan ibu dan anak. Ibu hamil ialah salah satu kelompok yang rawan akan masalah gizi. Organisasi Kesehatan Dunia (WHO) melaporkan bahwa prevalensi kurang energi kronik (KEK) pada kehamilan secara global 3575\% dimana secara bermakna tinggi pada trimester ketiga dibandingkan dengan trimester pertama dan kedua kehamilan. WHO juga mencatat $40 \%$ kematian ibu di 
negara berkembang berkaitan dengan kekurangan energi kronik. ${ }^{1}$

Kejadian kekurangan energi kronik di negara-negara berkembang seperti Bangladesh, India, Indonesia, Myanmar, Nepal, Srilanka dan Thailand adalah 1547\% yaitu dengan BMI <18,5. Adapun negara yang mengalami kejadian yang tertinggi adalah Bangladesh yaitu 47\%, sedangkan Indonesia merupakan urutan keempat terbesar setelah India dengan prevalensi $35,5 \%$ dan yang paling rendah adalah Thailand dengan prevalensi 15$25 \%$. $^{1}$

Disamping menunjukkan derajat kesehatan masyarakat, juga dapat menggambarkan tingkat kesejahteraan masyarakat dan kualitas pelayanan kesehatan. Pemenuhan gizi bagi ibu hamil memegang peran yang signifikan dalam menurunkan Angka Kematian Ibu (AKI), Angka Kematian Bayi (AKB) dan menentukan kualitas anak yang akan dilahirkannya. Pembangunan dibidang kesehatan tidak bisa dilepaskan dari upaya mewujudkan kesehatan anak sedini mungkin sejak dalam kandungan. Anemia gizi sering kali disebabkan kurangnya asupan zat besi pada makanan yang dikonsumsi setiap hari. Bayi dalam kandungan dapat mengalami gangguan pertumbuhan dan perkembangan, serta setelah bayi lahir kemungkinan tidak dapat mencapai tinggi yang optimal dan anak menjadi kurang cerdas. ${ }^{1,2}$
Masalah ibu hamil KEK merupakan salah satu fokus perhatian dan menjadi salah satu indikator kinerja program Kementerian Kesehatan, karena berdasarkan Riset Kesehatan Dasar (Riskesdas) tahun 2018, prevalensi risiko KEK pada ibu hamil (15-49 tahun) masih cukup tinggi yaitu sebesar 33,5\%. Prevalensi tertinggi ditemukan pada usia remaja (15-19 tahun) sebesar 33,5\% dibandingkan dengan kelompok lebih tua (40-44 tahun) sebesar 6,5\%. Indikator persentase ibu hamil KEK naik, prevalensi risiko KEK pada ibu hamil pada tahun 2013(15-49 tahun) masih cukup tinggi yaitu sebesar $24,2 \%$. Pada awal periode di tahun 2015, persentase ibu hamil KEK ditargetkan tidak melebihi $24,2 \%$, dan diharapkan di akhir periode pada tahun 2019, maksimal ibu hamil dengan risiko KEK adalah sebesar 18,2\%. Dasar penetapan persentase bumil KEK mengacu kepada hasil Riskesdas tahun 2013.

Kekurangan energi kronik adalah manifestasi penting dari kekurangan gizi buruk dan juga kedua masalah utama di negara berkembang. Berdasarkan hasil Riset Kesehatan Dasar (Riskesdas) di Indonesia tahun 2013, Kurang Energi Kronik (KEK) menjadi masalah yang kedua. Hal ini disebabkan karena angka KEK mengalami peningkatan dari tahun 2010 yaitu $31,3 \%$ menjadi $38,5 \%$ di tahun 2013.

Menurut Badan Puslitbang Gizi dan Makanan Depkes RI di Jawa Barat pada 
tahun 2005, angka kejadian KEK 30,6 \% dengan yang paling rendah di Kota Cimahi sekitar 19,5\% dan yang tertinggi di daerah Kabupaten Purwakarta sekitar 50,7\%. Untuk daerah Kabupaten Sumedang sendiri mencapai 29,7\%.7 Data di atas menunjukan, angka tersebut cukup tinggi mengingat cakupan target pemeriksaan ANC menurut Rencana Strategis Kementrian Kesehatan (Renstra 2013) yang meliputi pemeriksaan Lingkar Lengan Atas (LILA) untuk K1 dan K4 adalah 93\%."

KEK pada ibu hamil dapat menyebabkan resiko dan komplikasi pada ibu antara lain: anemia, pendarahan, berat badan ibu tidak bertambah secara normal, dan terkena penyakit infeksi. Pengaruh KEK terhadap proses persalinan dapat mengakibatkan persalinan sulit dan lama, persalinan sebelum waktunya (prematur), pendarahan setelah persalinan, serta persalinan dengan operasi cenderung meningkat. Pertumbuhan intrauterin yang optimal sangat diperlukan untuk perkembangan janin dan berkontribusi terhadap kesehatan jangka panjang. Pertumbuhan janin dipengaruhi oleh interaksi antara faktor genetik, nutrisi, hormonal dan faktor lingkungan. Kekurangan KEK ibu hamil dapat mempengaruhi proses pertumbuhan janin dan dapat menimbulkan keguguran, abortus, bayi lahir mati, kematian neonatal, cacat bawaan, anemia pada bayi, asfiksia intrapartum (mati dalam kandungan), lahir dengan berat badan lahir rendah (BBLR). ${ }^{5}$
Hasil penelitian tentang pertumbuhan anak Indonesia menunjukkan bahwa kegagalan pertumbuhan paling gawat terjadi pada usia 6-18 bulan. Penyebab gagal tumbuh tersebut adalah keadaan gizi ibu selama hamil, pola makan bayi yang salah, dan penyakit infeksi. Berbagai penelitian menunjukkan bahwa status gizi ibu tidak hanya memberikan dampak negatif terhadap status kesehatan dan resiko kematian dirinya, tetapi juga terhadap kelangsungan hidup dan perkembangan janin yang dikandungnya dan lebih jauh lagi terhadap pertumbuhan janin tersebut sampai usia dewasa. ${ }^{9,10}$

Berdasarkan latar belakang diatas, maka penulis tertarik untuk melakukan penelitian dengan judul "hubungan antara ibu dengan kurang energi kronik (kek) pada masa kehamilan terhadap pertumbuhan dan perkembangan balita usia 6-18 bulan di puskesmas Cipeundeuy tahun 2018".

\section{TINJAUAN PUSTAKA}

1. Kurang Energi Kronik (KEK)

Kekurangan Energi Kronik (KEK) adalah keadaan di mana seseorang ibu hamil yang mengalami kekurangan gizi (kalori dan protein) yang berlangsung lama atau menahun. Risiko Kekurangan Energi Kronik (KEK) adalah keadaan di mana seseorang mempunyai kecenderungan menderita KEK. Seseorang dikatakan menderita risiko KEK bilamana LILA (Lingkar Lengan Atas) $<23,5 \mathrm{~cm}$. 
2. Pertumbuhan

Pertumbuhan (growth) berkaitan dengan masalah perubahan ukuran, besar, jumlah atau dimensi pada tingkat sel, organ maupun individu. Pertumbuhan bersifat kuantitatif sehingga dapat diukur dengan satuan berat (gram, kilogram), satuan panjang $(\mathrm{cm}, \mathrm{m})$, umur tulang, dan keseimbangan metabolik (retensi kalsium dan nitrogen dalam tubuh). ${ }^{7}$

Pertumbuhan mempunyai ciriciri khusus, yaitu perubahan ukuran, perubahan proporsi, hilangnya ciri-ciri lama, serta munculnya ciri-ciri baru. Keunikan pertumbuhan adalah mempunyai kecepatan yang berbedabeda di setiap kelompok umur dan masing-masing organ juga mempunyai pola pertumbuhan yang berbeda. Terdapat 3 periode pertumbuhan cepat, yaitu masa janin, masa bayi $0-1$ tahun, dan masa pubertas. ${ }^{9}$

3. Perkembangan

\section{Perkembangan}

(development) adalah bertambahnya kemampuan (skill) dalam struktur dan fungsi tubuh yang lebih kompleks dalam pola yang teratur dan dapat diramalkan, sebagai hasil dari proses pematangan. Disini menyangkut adanya proses diferensiasi dari sel-sel tubuh, jaringan tubuh, organ-organ dan sistem organ yang berkembang sedemikian rupa sehingga masingmasing dapat memenuhi fungsinya. Termasuk juga perkembangan emosi, intelektual dan tingkah laku sebagai hasil interaksi dengan lingkungannya. ${ }^{7}$

Proses perkembangan terjadi secara simultan dengan pertumbuhan, sehingga setiap pertumbuhan disertai dengan perubahan fungsi. Perkembangan merupakan hasil interaksi kematangan susunan saraf pusat dengan organ yang dipengaruhinya. Perkembangan fase awal meliputi beberapa aspek kemampuan fungsional, yaitu kognitif, motorik, emosi, sosial, dan bahasa. Perkembangan pada fase awal ini akan menentukan perkembangan fase selanjutnya. Kekurangan pada salah satu aspek perkembangan dapat mempengaruhi aspek lainnya. ${ }^{9}$

\section{METODE PENELITIAN}

Jenis penelitian ini menggunakan penelitian survey analitik, dan desain penelitian menggunakan analitik retrospektif dengan pendekatan cross sectional. Dimana variabel independen dan variabel dependen diobservasi hanya sekali pada saat waktu yang bersamaan. Dengan menggunakan data rekam medik/register, buku laporan persalinan dan buku laporan sdidtk yang digunakan untuk mengetahui adanya hubungan antara ibu dengan kurang energi kronik (kek) pada masa kehamilan terhadap pertumbuhan dan perkembangan balita usia $6-18$ bulan periode 2018 . 
HASIL PENELITIAN DAN

PEMBAHASAN

1. Kekurangan Energi Kronik (KEK)

Tabel.4.1.1 Angka Kejadian Kekurangan Energi Kronik (KEK) Puskesmas Cipeundeuy.

\begin{tabular}{ccc}
\hline Status Ibu & $\begin{array}{c}\text { Frekuensi } \\
(\mathbf{f})\end{array}$ & $\begin{array}{c}\text { Persentase } \\
(\boldsymbol{\%})\end{array}$ \\
\hline KEK & 49 & 7,4 \\
TIDAK & 613 & 92,6 \\
KEK & & 100 \\
\hline Total & 662 & \\
\hline
\end{tabular}

Diketahui bahwa dari total 662 ibu bersalin menunjukan bahwa terdapat ibu dengan KEK pada masa kehamilan sebanyak $49(7,4 \%)$ dan tidak KEK sebanyak $613(92,6 \%)$

Berdasarkan analisis di lapangan, dapat diketahui bahwa responden yang memiliki ukuran LILA $<23,5 \mathrm{~cm}$ atau ibu hamil dengan KEK dari total $662 \mathrm{ibu}$ hamil menunjukan bahwa terdapat ibu dengan kek pada masa kehamilan sebanyak $49(7,4 \%)$ dimana hal ini disebabkan dari beberapa faktor, yang peneliti temukan dilapangan yaitu faktor pola makan positif 38 responden $(54,3 \%)$ dan negatif 32 responden $(45,7 \%)$ dan pendidikan $27(38,6 \%)$. Pola makan dan gaya hidup sehat dapat membantu pertumbuhan dan perkembangan janin dalam rahim ibu. Pengaturan gizi pada wanita hamil diperlukan untuk mencapai status gizi ibu yang optimal sehingga ibu menjalani kehamilan dengan aman serta melahirkan bayi dengan potensi fisik dan mental yang baik. ${ }^{17}$
Tingkat pendidikan akan berpengaruh terhadap pemilihan bahan makanan dan pemenuhan kebutuhan gizi. Kelompok orang dengan pendidikan tinggi memiliki kecenderungan memilih bahan-bahan makanan sumber protein dan akan berusaha menyeimbangkan dengan kebutuhan gizi lain. Tingkat pendapatan keluarga yang cukup akan meningkatkan peluang untuk membeli pangan dengan kuantitas dan kualitas yang lebih baik, sebaliknya penurunan pendapatan akan menyebabkan penurunan daya beli pangan baik secara kualitas maupun kuantitas. ${ }^{18}$

Hal ini serupa dengan penelitian dari Fitrianingsih dengan judul "Hubungan Pola Makan Dan Status Sosial Ekonomi Dengan Kejadian Kekurangan Energi Kronik (Kek) Pada Ibu Hamil Di Puskesmas Tompobulu Kabupaten Gowa Tahun 2014" dimana menunjukkan hasil bahwa terdapat hubungan yang bermakna antara pola makan $(p=0,02)$, pendidikan terakhir $(p$ $=0,04){ }^{19}$

\section{Angka Kejadian Pertumbuhan dan} Perkembangan Balita Usia 6-18 bulan

Tabel.4.1.2 Angka Kejadian Pertumbuhan balita usia 6-18 bulan

\begin{tabular}{ccc}
\hline Pertumbuhan & $\begin{array}{c}\text { Frekuensi } \\
\text { (f) }\end{array}$ & $\begin{array}{c}\text { Persentase } \\
(\%)\end{array}$ \\
\hline Sesuai & 615 & 92,9 \\
Tidak Sesuai & 47 & 7,1 \\
\hline Total & 662 & 100
\end{tabular}


Diketahui dari 662 anak dengan kategori pertumbuhan sesuai 615 $(92,9 \%)$ dan dengan kategori tidak sesuai $47(7,1 \%)$.

Tabel.4.1.3 Angka Kejadian Perkembangan balita usia 6-18 bulan

\begin{tabular}{ccc}
\hline Perkembangan & $\begin{array}{c}\text { Frekuensi } \\
\text { (f) }\end{array}$ & $\begin{array}{c}\text { Persentase } \\
(\mathbf{\%})\end{array}$ \\
\hline Sesuai & 599 & 90,2 \\
Meragukan & 50 & 7,6 \\
Penyimpangan & 13 & 2,0 \\
\hline Total & $\mathbf{6 6 2}$ & $\mathbf{1 0 0}$ \\
\hline
\end{tabular}

Diketahui dari 662 anak dengan

kategori perkembangan sesuai 599 $(90,2 \%)$, kategori meragukan $50(7,6 \%)$ dan kategori penyimpangan 13 (2,0\%).

\section{Hubungan Antara Ibu Dengan}

\section{Kurang Energi Kronik (KEK) Pada}

\section{Masa Kehamilan Terhadap}

\section{Pertumbuhan Balita Usia 6-18 Bulan}

Berdasarkan hasil penelitian yang telah dilakukan di Puskesmas Cipeundeuy mengenai angka kejadian pertumbuhan pada balita usia 6-18 bulan diketahui bahwa dari 662 ibu dengan riwayat KEK pada masa kehamilan melahirkan bayi dan memiliki pertumbuhan dengan kategori sesuai 615 $(92,9 \%)$ dan dengan kategori tidak sesuai $47(7,1 \%)$.

Menurut hasil penelitian tentang pertumbuhan anak Indonesia menunjukkan bahwa kegagalan pertumbuhan paling gawat terjadi pada usia 6-18 bulan. Proses terjadinya KEK merupakan akibat dari faktor lingkungan dan faktor manusia yang didukung oleh kekurangan asupan zat-zat gizi, mekanisme pangan zat gizi pada tubuh digunakan untuk memenuhi kebutuhan. Apabila keadaan ini berlangsung lama maka simpanan zat gizi akan habis dan akhirnya terjadi kemerosotan jaringan. ${ }^{11,}$ 13

Tabel 4.1.4 Hubungan Antara Ibu Dengan Kurang Energi Kronik (KEK) Pada Masa Kehamilan Terhadap Pertumbuhan Balita Usia 6-18 Bulan Di Puskesmas Cipeundeuy.

\begin{tabular}{cccccccc}
\hline \multirow{2}{*}{$\begin{array}{c}\text { Kejadian } \\
\text { KEK }\end{array}$} & \multicolumn{2}{c}{$\begin{array}{c}\text { Tidak } \\
\text { Sesuai }\end{array}$} & \multicolumn{2}{c}{ Sesuai } & \multicolumn{2}{c}{ Total } & $\begin{array}{c}\text { Nilai } \boldsymbol{P} \\
\text { Value }\end{array}$ \\
& $(\mathbf{f})$ & $(\boldsymbol{\%})$ & $(\mathbf{f})$ & $(\boldsymbol{\%})$ & $(\mathbf{F})$ & $(\boldsymbol{\%})$ & \\
\hline $\begin{array}{c}\text { Tidak KEK } \\
\text { KEK }\end{array}$ & 29 & 4,7 & 584 & 95,3 & 613 & 100 & $0,000^{*}$ \\
\hline
\end{tabular}

* Berdasarkan uji Kolmogorov-smirnov

Diketahui dari Tabel 4.1.4 terdapat $662 \mathrm{ibu}$ bersalin, terdapat 49 $(7,4 \%)$ ibu dengan KEK pada masa kehamilan, dimana anak dari ibu tersebut sebanyak $18(36,7 \%)$ dengan pertumbuhannya tidak sesuai, 31 $(63,3 \%)$ dengan pertumbuhan sesuai. Berdasarkan hasil uji kolmogorovsmirnov, diperoleh p-value sebesar 0,000 . Oleh karena nilai $p$-value sebesar 
0,000 kurang dari 0,05 $(\mathrm{p}<0,05)$, artinya secara statistik terbukti terdapat hubungan yang signifikan antara ibu dengan KEK pada masa kehamilan terhadap pertumbuhan balita usia 6-18 bulan di Puskesmas Cipeundeuy tahun 2018.

Bayi dalam kandungan dapat mengalami gangguan pertumbuhan dan perkembangan, serta setelah bayi lahir kemungkinan tidak dapat mencapai tinggi yang optimal dan anak menjadi kurang cerdas. Sebelum lahir, anak tergantung pada zat gizi yang terdapat dalam darah ibu. Setelah lahir, anak tergantung pada tersedianya bahan makanan dan kemampuan saluran cerna. 2,7

Berbagai penelitian menunjukkan bahwa status gizi ibu tidak hanya memberikan dampak negatif terhadap status kesehatan dan resiko kematian dirinya, tetapi juga terhadap kelangsungan hidup dan perkembangan janin yang dikandungnya dan lebih jauh lagi terhadap pertumbuhan janin tersebut sampai usia dewasa. ${ }^{9,10}$

Hasil temuan ini sesuai dengan teori, peneliti menemukan faktor lain yang mempengaruhi pertumbuhan selain dari faktor prenatal, yang berpengaruh yaitu faktor postnatal seperti Faktor biologis (gizi) dan Faktor keluarga (pendapatan orangtua, pendidikan orangtua dan pengetahuan ibu) ${ }^{7}$

\section{Hubungan Antara Ibu Dengan} Kurang Energi Kronik (KEK) Pada

\section{Masa Kehamilan Terhadap}

\section{Perkembangan Balita Usia 6-18 Bulan}

Dari Tabel 4.1.5 terdapat $662 \mathrm{ibu}$ bersalin, terdapat $49(7,4 \%)$ ibu dengan KEK pada masa kehamilan, dimana anak dari ibu tersebut sebanyak 29 $(59,2 \%)$ dengan perkembangan sesuai, $14(28,6 \%)$ dengan perkembangan meragukan dan $6 \quad(12,2 \%)$ dengan perkembangan penyimpangan. Berdasarkan hasil uji kolmogorovsmirnov diperoleh p-value sebesar 0,014 . Oleh karena nilai $p$ value sebesar 0,014 kurang dari $0,05(\mathrm{p}<0,05)$, artinya secara statistik terbukti terdapat hubungan yang signifikan antara ibu dengan KEK pada masa kehamilan terhadap perkembangan balita usia 6-18 bulan di Puskesmas Cipeundeuy tahun 2018.

Berdasarkan hasil penelitian terdapat hubungan ibu hamil dengan riwayat KEK dengan perkembangan pada balita usia 6-18 bulan dimana perkembangan pada kategori meragukan $14(28,6 \%)$ dan $6(12,2 \%)$ dengan perkembangan kategori penyimpangan. Menurut penelitian Atien Nur Chamidah kemajuan perkembangan anak mengikuti suatu pola yang teratur dan mempunyai variasi pola batas pencapaian dan kecepatan. Batasan usia menunjukkan bahwa suatu patokan kemampuan harus dicapai pada usia 
tertentu. Batas ini menjadi penting dalam penilaian perkembangan, apabila anak gagal mencapai dapat memberikan petunjuk untuk segera melakukan penilaian yang lebih terperinci dan intervensi yang tepat. ${ }^{9}$

Tabel 4.1.5 hubungan antara ibu dengan kurang energi kronik (KEK) pada masa kehamilan terhadap perkembangan balita usia 6-18 bulan di puskesmas Cipeundeuy

\begin{tabular}{|c|c|c|c|c|c|c|c|c|c|}
\hline \multirow{3}{*}{$\begin{array}{l}\text { Kejadian } \\
\text { KEK }\end{array}$} & \multicolumn{8}{|c|}{ Perkembangan } & \multirow{3}{*}{$\begin{array}{c}\text { Nilai } p \\
\text { Value }\end{array}$} \\
\hline & \multicolumn{2}{|c|}{ Sesuai } & \multicolumn{2}{|c|}{ Meragukan } & \multicolumn{2}{|c|}{ Penyimpangan } & \multicolumn{2}{|c|}{ Total } & \\
\hline & (f) & $(\%)$ & (f) & $(\%)$ & (f) & $(\%)$ & (F) & $(\%)$ & \\
\hline \multirow{2}{*}{$\begin{array}{c}\text { Tidak KEK } \\
\text { KEK }\end{array}$} & 570 & 93,1 & 36 & 5,9 & 7 & 1 & 613 & 92,6 & \multirow{2}{*}{$0,014 *$} \\
\hline & 29 & 59,2 & 14 & 28,6 & 6 & 12,2 & 49 & 100 & \\
\hline
\end{tabular}

*Berdasarkan uji Kolmogorov-smirnov

Malnutrisi ibu yang lama dan berkelanjutan selama masa kehamilan akan berakibat lebih buruk terhadap bayi daripada malnutrisi akut yang terjadi selama kehamilan pada seorang ibu yang sebelumnya memperlihatkan keadaan gizi baik. Akibat jangka panjang pada anak akan lebih buruk dan mengkhawatirkan, bila malnutrisi intrauterine tersebut berlanjut sampai usia 1 bulan postnatal; bahkan akan tetap berpengaruh terhadap tumbuhkembang selanjutnya, khususnya di negara yang sedang berkembang karena adanya tambahan pengaruh negatif berbagai faktor lingkungan ekstrauterin sepanjang masa bayi maupun balita. ${ }^{21}$

Kekhawatiran akibat malnutrisi akan lebih dirasakan bila diperhatikan dampaknya terhadap struktur dan fungsi otak pada masa kehidupan mendatang. Dimana struktur dan fungsi otak pada perkembangan otak dimulai saat bayi dalam kandungan. Kecukupan makanan dan gizi yang seimbang mempengaruhi pembentukan otak. Oleh karena itu, sangat penting bagi ibu hamil untuk mengkonsumsi makanan yang cukup dan bergizi. Kekurangan makanan dan gizi menyebabkan pertumbuhan otak dan badan bayi tidak optimal. ${ }^{21,22}$

Berbagai faktor mempengaruhi perkembangan tersebut. Secara umum faktor tersebut ialah faktor genetik dan faktor lingkungan. Faktor lingkungan antara lain mencakup makanan yang bergizi, perilaku sehat ibu, kondisi emosi ibu, penyakit, dan stimulasi dini. Dengan menelaah kenyataan tersebut dapat disimpulkan bahwa pengaruh malnutrisi pada masa pertumbuhan intrauterin dan 18 postnatal akan berakibat lebih buruk, yaitu bukan hanya terhadap pertumbuhan fisis, 
bahkan juga terhadap perkembangan intelektual anak di masa mendatang. Sehingga setiap kelainan/penyimpangan sekecil apapun apabila tidak terdeteksi apalagi tidak ditangani dengan baik, akan mengurangi kualitas sumber daya manusia kelak kemudian hari. ${ }^{7,21}$

\section{PENUTUP}

\section{Simpulan}

1. Penelitian ini sebagian besar dengan riwayat tidak KEK pada masa kehamilan yaitu 613 orang $(92,6 \%)$.

2. Pada kejadian pertumbuhan dan perkembangan balita usia 6-18 bulan terbanyak pertumbuhan kategori sesuai $18(2,7 \%)$ dan perkembangan sesuai 29 $(59,2 \%)$.

3. Berdasarkan uji kolmogorov-smirnov, terdapat hubungan antara ibu dengan KEK pada masa kehamilan dengan pertumbuhan dan perkembangan balita usia 6-18 bulan. Didapatkan nilai $p$ value $=0,000$ pada pertumbuhan dan $p$ value $=0,015$ pada perkembangan.

\section{Saran}

1. Bagi Pelayanan Kesehatan

Tenaga kesehatan terutama yang bekerja langsung di masyarakat khususnya bidan diharapkan agar meningkatkan pengetahuan dan keterampilan agar dapat memberikan informasi kepada masyarakat untuk lebih memperhatikan kesehatanya dan gizi/pola makan terutama pada saat kehamilan, diharapkan meningkatkan kualitas deteksi dini KEK pada ibu hamil terutama pada kunjungan ANC pertama dengan dilakukannya pengukuran LILA pada ibu hamil.

Selain itu diharapkan juga tenaga kesehatan khususnya bidan untuk lebih memperhatikan pertumbuhan dan perkembangan anak usia 6-18, dikarenakan hasil penelitian pertumbuhan anak Indonesia menunjukkan bahwa kegagalan pertumbuhan paling gawat terjadi pada usia 6-18 bulan. Diharapkan juga dapat mengetahui apa saja faktor penyebab dari KEK dan faktor resiko dari KEK.

2. Poltekes TNI AU Ciumbuleuit Bandung

Diharapkan bagian dari sarana perpustakaan dapat menambah bukubuku sumber mengenai penelitian dan kebidanan, juga jurnal yang dapat menjadi referensi dalam sebuah penelitian, serta untuk menambah wawasan bagi mahasiswa terutama KEK dan pertumbuhan perkembangan anak.

3. Bagi Peneliti Selanjutnya

Peneliti selanjutnya dapat mengembangkan penelitian mengidentifikasi lebih luas dan dalam mengenai KEK dengan memperluas variabel yang akan diteliti.

\section{DAFTAR PUSTAKA}

Marianita manik r. Faktor yang berpengaruh terhadap kenaikan berat badan ibu Hamil dengan kek pada trimester iii. Jurnal ilmiah kesehatan. 2017;16:31. 
Sri astuti ai, rani nurparidah,ariyati mandiri. Asuhan ibu dalam masa kehamilan. Evie kemala dewi ra, editor. Jakarta2016.

Kesehatan djkmk. Laporan kinerja direktorat jenderal kesehatan masyarakat tahun 2017. 2018.

Arsy prawita ais, puspa sari. Survei intervensi ibu hamil kurang energi kronik (kek) di kecamatan jatinangor tahun 2015. 2015.

Sandjaja. Risiko kurang energi kronis (kek) pada ibu hamil di indonesia.

Moehji s. Ilmu gizi 2. Depok timur: papas sinar sinanti; 2013.

Soetjiningsih d. Tumbuh kembang anak. Jakarta: buku kedokteran egc; 1995.

Ayu bulan febry $\mathrm{k} \mathrm{d}$ sk, dkk. Ilmu gizi untuk praktisi kesehatan yogyakarta: graha ilmu; 2013.

Chamidah an. Deteksi dini gangguan pertumbuhan dan perkembangan anak. 2013.

Albugis d. Faktor-faktor yang berhubungan dengan kurang energi kronik pada ibu hamil di puskesmas jembatan serong kec. Pancoran mas depok. 2008.

Agustian en. Hubungan antara asupan protein dengan kekurangan energi kronik (kek) pada ibu hamil di kecamatan jebres surakarta. Karya tulis ilmiah. 2010.

Sandra fikawati as, ph.d,khaula karima, s.gz. Gizi ibu dan bayi. Jakarta: kharisma putra utama offset; 2015.

Putri mc. Hubungan asupan makan dengan kejadian kurang energi kronis (kek) pada wanita usia subur (wus) di kecamatan terbanggi besar kabupaten lampung tengah. 2017.

Kartikasari bw. Hubungan pendidikan, paritas, dan pekerjaan ibu dengan status Gizi ibu hamil trimester iii di puskesmas bangetayu kecamatan Genuk kota semarang tahun 2011. 2011.

Alimul a. Metode penelitian kebidanan teknik analisis data. Jakarta: salemba medika; 2012.

$\mathrm{S}$ n. Metodologi penelitian kesehatan. Jakarta: rineka cipta; 2010.
T. D. 58 qa seputar diet, makanan, dan suplemen. Jakarta: penebar swadaya grup; 2012.

D s. Penilaian status gizi. Jakarta: penerbit buku kedokteran egc; 2002.

Fitrianingsih. Hubungan pola makan dan status sosial ekonomi dengan kejadian kekurangan energi kronik (kek) pada ibu hamil di puskesmas tompobulu kabupaten gowa tahun 2014. 2014.

Sartono. Hubungan kurang energi kronis ibu hamil dengan kejadian stunting pada anak usia 6-24 bulan. 2013.

Markum ah. Buku ajar ilmu kesehatan anak. Jakarta: fakultas kedokteran universitas indonesia 1991.

Suyanto s. Hasil kajian neuroscience dan implikasinya dalam pendidikan. 2008. 